\title{
Expression kinetics of natural resistance associated macrophage protein (NRAMP) genes in Salmonella Typhimurium-infected chicken
}

Mashooq Ahmad Dar ${ }^{1,2}$, Raashid Ahmed ${ }^{1}$, Uneeb Urwat ${ }^{1}$, Syed Mudasir Ahmad ${ }^{1 *}$ (D) Pervaiz Ahmad Dar ${ }^{3}$, Zahid Amin Kushoo ${ }^{3}$, Tanveer Ali Dar², Peerzada Tajamul Mumtaz', Shakil Ahmad Bhat', Umar Amin', Nadeem Shabir ${ }^{1}$, Hina Fayaz Bhat ${ }^{1}$, Riaz Ahmad Shah ${ }^{1}$, Nazir Ahmad Ganai ${ }^{5}$ and Mohammad Heidari ${ }^{6}$

\begin{abstract}
Background: Salmonella enterica serovar Typhimurium (Salmonella Typhimurium) is a zoonotic pathogen responsible for severe intestinal pathology in young chickens. Natural resistance-associated macrophage protein (NRAMP) family has been shown to be associated with resistance to intracellular pathogens, including Salmonella Typhimurium. The role of NRAMP proteins in macrophage defence against microbial infection has been ascribed to changes in the metalion concentrations inside the bacteria-containing phagosomes. The present study was conducted to investigate tissuespecific (liver, spleen and caecum) expression kinetics of NRAMP gene family (NRAMP1 and NRAMP2) in broilers from day 0 to day 15 after Salmonella Typhimurium challenge concomitant to clinical, blood biochemical and immunological parameters survey.

Results: Clinical symptoms appeared 4 days post-infection (dpi) in infected birds. Symptoms like progressive weakness, anorexia, diarrhoea and lowering of the head were seen in infected birds one-week post-infection. On postmortem examination, liver showed congestion, haemorrhage and necrotic foci on the surface, while as the spleen, lungs and intestines revealed congestion and haemorrhages. Histopathological alterations were principally found in liver comprising of necrosis, reticular endothelial hyperplasia along with mononuclear cell and heterophilic infiltration. Red Blood Cell (RBC) count, Haemoglobin $(\mathrm{Hb})$ and Packed Cell Volume (PCV) decreased significantly $(P<0.05)$ in blood while heterophil counts increased up to 7 days post-infection. Serum glucose, aspartate transaminase (AST) and alanine transaminase (ALT) enzymes concentrations increased significantly throughout the study. A gradual increase of specific humoral lgG response confirmed Salmonella infection. Meanwhile, expression of NRAMP1 and NRAMP2 genes was differentially regulated after infection in tissues such as liver, spleen and caecum known to be the target of Salmonella Typhimurium replication in the chicken.

Conclusion: Thus the specific roles of NRAMP1 and NRAMP2 genes in Salmonella Typhimurium induced disease may be supposed from their differential expression according to tissues and timing after per os infection. However, these roles remain to be analyzed related to the severity of the disease which can be estimated by blood biochemistry and immunological parameters.
\end{abstract}

Keywords: Salmonella Typhimurium, Poultry, Histopathology, Biochemistry, Real time expression, NRAMP

\footnotetext{
* Correspondence: mudasirbio@gmail.com

${ }^{1}$ Division of Biotechnology, Faculty of Veterinary Sciences and Animal

Husbandry, Shuhama, Sher-e- Kashmir University of Agricultural Sciences and

Technology - Kashmir, Srinagar, India

Full list of author information is available at the end of the article
}

(c) The Author(s). 2018 Open Access This article is distributed under the terms of the Creative Commons Attribution 4.0 International License (http://creativecommons.org/licenses/by/4.0/), which permits unrestricted use, distribution, and

reproduction in any medium, provided you give appropriate credit to the original author(s) and the source, provide a link to the Creative Commons license, and indicate if changes were made. The Creative Commons Public Domain Dedication waiver (http://creativecommons.org/publicdomain/zero/1.0/) applies to the data made available in this article, unless otherwise stated. 


\section{Background}

Salmonella is an intracellular pathogenic, gram negative, facultative anaerobe, non-spore forming, and usually motile bacilli that leads to salmonellosis in the host. Among the different diseases occurring in poultry, those caused by the genus Salmonella are the most common, causing serious economic losses to the poultry industry in terms of mortality, reduced growth and loss in egg production [1]. Salmonella infection can reach eggs either through vertical or horizontal transmission thus making it an important zoonotic disease [2]. Salmonellosis is a big socioeconomic threat worldwide that causes considerable mortality and morbidity in both humans and animals [3]. Owing to growing public health concern, prevention of foodborne transmission of Salmonella spp. remains one of the major foci for the poultry sector [4]. The gastrointestinal (GI) tract of newly hatched chickens is usually sterile and presents an empty ecological niche that provides easy access for the pathogen to colonize with limited restriction making them highly susceptible to enteric bacterial infections, such as Salmonella [5]. After ingestion, the bacteria can survive the acidic $\mathrm{pH}$ of the stomach and is taken via microfold (M)-cells and reach liver and spleen through the hepatic portal system where the bacteria multiply in macrophages of reticuloendothelial system [6]. Many genes such as Major Histocompatibility Complex (MHC), Caspase1, NRAMP Family, inducible nitric oxide synthase (iNOS), those encoding complement proteins and Toll-like Receptor 4 (TLR4) have been found to be associated with resistance against Salmonella infection in poultry [7].

The Solute Carrier Family (SLC11A), formerly known as natural resistance associated macrophage protein family functions as metal ion transporters in diverse organisms from bacteria to human [8]. Iron is essential for the survival of bacteria inside the macrophages and any impairment in iron homeostasis may promote inappropriate immune responses thereby affecting the host resistance to infectious diseases [9]. Iron transporter natural resistance-associated macrophage protein 1 (NRAMP1/SLC11A1), the member of the solute carrier (SLC11A) family of ion transporters [10] has certain genotypes that provide resistance to wide range of intracellular pathogens including Salmonella Typhimurium [11]. NRAMP1 is an antiporter, expressed on phagosomes and primary phagolysosomes [12] that transports iron into the phagosome [13], where it catalyzes the Haber-Weiss reaction [14]. This results in an increase in the production of highly microbicidal hydroxyl radicals that inhibit bacterial growth. SLC11A2 formerly known as NRAMP2/ DMT1 is ubiquitously expressed in all tissues including the brush border of intestinal epithelial cells and is involved in transport of divalent cations into the cytosol of cells as well as intestinal absorption of iron, while as NRAMP1 has more restricted expression but is especially associated with myeloid lineage cells and the liver, thymus and spleen [15-18]. Polymorphisms in the NRAMP1 gene have been found to be significantly associated with caecal Salmonella colonization, and expression of NRAMP1 gene can accelerate inflammatory responses in caecum [19]. NRAMP1 plays an important role in modulating the growth of bacteria that reach the reticuloendothelial system during early infection [20]. Association of NRAMP1 Ser ${ }^{379}$ polymorphism with Salmonella colonization of the spleen has been found in young chickens and also linkage analysis studies have shown that NRAMP1 is associated with resistance in Salmonella Typhimurium-infected chicken and mice [21-23]. NRAMP2 is expressed in almost all tissues in Salmonella-infected chicken [24]. However, detailed studies of expression kinetics of NRAMP genes in liver and spleen (that form the hepatoportal system) and caecum in chicken at different days post Salmonella Typhimurium infection has not been carried out. Thus, the present study was conducted to investigate the mRNA expression kinetics of NRAMP1 and NRAMP2 in liver, spleen and caecum of birds challenged with Salmonella Typhimurium in relation with blood physiological and immunological parameters along with the disease severity.

\section{Methods \\ Experimental birds}

Cobb breeding flock procured from the Hariparbat hatchery Srinagar, Department of Animal Husbandry government of Jammu and Kashmir, India, was maintained under strict hygienic conditions at the experimental housing of Faculty of Veterinary Science and Animal Husbandry, Sher-e-Kashmir University of Agricultural Sciences and Technology, Kashmir, India and the work was agreed upon by the Institutional Animal Ethics Committee on ethical standards in animal experimentation (No: AU/FVS/PS-57/4461) (IAEC/15/01).

\section{Salmonella Typhimurium strain}

For the development of infection in experimental birds, Salmonella Typhimurium was isolated in the field from fecal and liver samples of salmonellosis-suspected chicks at the Division of Veterinary Pathology, F.V.Sc and AH, Shuhama, Srinagar Jammu and Kashmir-India. Samples were inoculated in tetrathionate broth (TTB) and incubated at $37{ }^{\circ} \mathrm{C}$ for $48 \mathrm{~h}$. The cultures were identified by a method as recommended [25]. The Salmonella Typhimurium was confirmed by PCR as described previously [26] and biochemical (IMViC) tests. For further confirmation serotyping was done at National Salmonella and Escherichia Centre (NSEC), Himachal Pradesh, India. 


\section{Experimental design}

A total of 170 one day-old chickens were divided into two groups (control and infected) and were checked to be free of Salmonella infection before the challenge. After three days of acclimatization, the chicks in the infected group were challenged orally with $2 \times 10^{8} \mathrm{CFU}$ of Salmonella Typhimurium. Chicks in the control group were given $1 \mathrm{ml}$ of nutrient broth.

\section{Confirmation of infection}

Faecal swabs were taken $12 \mathrm{~h}$ after infection and cultured in TTB broth and incubated for $18 \mathrm{~h}$ at $37{ }^{\circ} \mathrm{C}$. The growth of TTB broth was streaked on BGA and MacConkey agar. These plates were incubated for $24-48 \mathrm{~h}$ at $37{ }^{\circ} \mathrm{C}$. The plates were examined for typical colonies of Salmonella i.e. pale colonies on MacConkey agar, pink colonies on Brilliant Green Agar (BGA).

\section{Sampling}

The birds were euthanized with $\mathrm{CO}_{2}$ and subsequently sharp cut was made in the neck to drain blood from vessels. Blood samples were collected for blood cell enumeration and biochemical analysis, and organs (liver, spleen and caecum) were collected for histopathological and gene expression studies from 6 birds randomly selected in each group at $0,1,3,5,7,9,11,13$ and 15 days post infection. For real time gene expression, tissue samples were collected in Trizol (Invitrogen, USA) and stored at $-80{ }^{\circ} \mathrm{C}$ for RNA extraction. The blood samples were analyzed for haemoglobin $(\mathrm{Hb})$, packed cell volume $(\mathrm{PCV})$, red blood cell (RBC) count, white blood cell (WBC) count, heterophils and lymphocyte count using Sysmex (KX-21) automated haematology analyzer. Serum samples were analyzed for alanine transaminase (ALT), aspartate transaminase (AST), total protein, serum albumin and glucose using commercially available kits.

\section{Histopathology}

For histopathological studies, representative liver tissue samples from infected and control birds were collected and fixed in $10 \%$ neutral buffered formalin. These were processed for paraffin embedding using alcohol as dehydrating agent and benzene as the clearing agent. The sections were cut at $4-5 \mu \mathrm{m}$ thickness and stained by the routine haematoxylin and eosin method [27].

\section{Enzyme linked immunosorbent assay (ELISA)}

Indirect ELISA was performed to detect the anti-Salmonella IgG antibodies in serum as per the method described [28]. Sonicated Salmonella Typhimurium $(20 \mathrm{ng} / 100 \mu \mathrm{l})$ was used as antigen. One hundred $\mu \mathrm{l}$ of goat anti-chicken antibody (Sigma 1:15000) diluted in PBS-T (Phosphate buffered saline -tween) was added to each well and plate was incubated at $37{ }^{\circ} \mathrm{C}$ for $2 \mathrm{~h}$. Plates were washed with PBS Tween-20 (0.05\%) and incubated with $100 \mu \mathrm{l}$ O-phenylene diamine dihydrochloride in the dark at room temperature for $15 \mathrm{~min}$. The reaction was stopped by adding $2 \mathrm{~N} \mathrm{H}_{2} \mathrm{SO}_{4}$ @ $50 \mu \mathrm{l}$ per well. Absorbance was determined using ELISA reader (PerkinElmer) at $492 \mathrm{~nm}$. Known positive $(n=5)$ and known negative $(n=22)$ controls were used in this study. The specificity was statistically calculated as.

Specificity $=\mathrm{T}_{\mathrm{N}} / \mathrm{T}_{\mathrm{N}}+\mathrm{F}_{\mathrm{P}}$.

Where $T_{N}$ denotes total negatives and $F_{P}$ denotes false positives.

\section{Gene expression analysis RNA extraction}

Total RNA was extracted from the tissue samples by Trizol method (Invitrogen, USA) as per manufacturer's protocol. The quantity and quality of isolated RNA were checked at 260 and $280 \mathrm{~nm}$ with UV-Visible spectrophotometer. Prior to cDNA synthesis, RNA samples were run on $1 \%$ agarose gel. DNase treatment using DNase1 kit (Sigma, USA) was given to rule out any genomic DNA contamination.

\section{CDNA synthesis}

cDNA synthesis was done with an equal concentration of RNA $(1.5 \mu \mathrm{g})$ in all the samples using Thermo Scientific RevertAid First Strand cDNA Synthesis $\mathrm{Kit}^{\mathrm{Tm}}$ (Lithuania) using oligo dT primers following manufacturer protocol. In conventional PCR, all primers produce only one amplification band visualized by agarose gel electrophoresis, indicating the specificity of the amplification. The primers used for NRAMP1 and $\beta$-actin gene amplification were already reported [24]. Primers for NRAMP2 were designed using PRIMER 3 Plus. (Table 1).

Table 1 List of primers used for real time PCR

\begin{tabular}{|c|c|c|c|c|c|}
\hline \multirow{2}{*}{$\frac{\text { Target }}{\beta \text { Actin }}$} & \multicolumn{2}{|c|}{ Primer sequence $\left(5^{\prime} \rightarrow 3^{\prime}\right)$} & \multirow{2}{*}{$\begin{array}{l}\text { Size of Amplicon } \\
160 \mathrm{bp}\end{array}$} & \multirow{2}{*}{$\frac{\mathrm{T}_{\mathrm{m}}{ }^{\circ} \mathrm{C}}{63.1}$} & \multirow{2}{*}{$\begin{array}{l}\text { Reference } \\
{[24]}\end{array}$} \\
\hline & Forward primer & TGGCATTGCTGACAGGAT & & & \\
\hline & Reverse primer & CTGCTTGCTGATCCACAT & & 60.0 & \\
\hline \multirow[t]{2}{*}{ NRAMP1 } & Forward primer & CCCCCACATCACCCCGTCC & $180 \mathrm{bp}$ & 74.2 & {$[24]$} \\
\hline & Reverse primer & GGCCCCACACTGCAGGTCTGAC & & 74.4 & \\
\hline \multirow[t]{2}{*}{ NRAMP2 } & Forward primer & GTACTCAGGGCAGTTCGTCA & $162 \mathrm{bp}$ & 63.0 & This study \\
\hline & Reverse primer & GCACGTTGAGGAAGTCGTTC & & 64.8 & \\
\hline
\end{tabular}




\section{Quantitative PCR}

For real time PCR, $\beta$-actin was used as internal control and SYBR green as fluorescent dye to quantify the mRNA level of chicken NRAMP1 and NRAMP2 genes by RT-PCR analysis. To confirm reproducibility, all determinations were performed at least two times. The reaction mixture contained $10 \mu \mathrm{L} 2 \mathrm{X}$ Q-PCR SYBR Green Mix (Roche), $0.3 \mu \mathrm{L} 10 \mu \mathrm{M}$ of each primer, $8.9 \mu \mathrm{L}$ ultrapure RNase-free water, and $0.5 \mu \mathrm{L} c \mathrm{cDN}$ to a final volume of $20 \mu \mathrm{L}$. Running program was performed in a Light cycler 480 II (Roche). All Aliquots were then amplified by 40 cycles of denaturation at $95{ }^{\circ} \mathrm{C}$ for $5 \mathrm{~min}$, annealing at $60{ }^{\circ} \mathrm{C}$ for $15 \mathrm{~s}$ and extension at $72{ }^{\circ} \mathrm{C}$ for $15 \mathrm{~s}$. Melting curve analysis was performed to confirm the specificity of the product. NRAMP1 and NRAMP2 mRNA relative expression was indicated by $2^{-\Delta \Delta C}$, where $\Delta \Delta \mathrm{C}_{\mathrm{T}}$ corresponded to the difference between the $\mathrm{C}_{\mathrm{T}}$ measured for the mRNA level of each tissue and the $\mathrm{C}_{\mathrm{T}}$ measured for the mRNA level of the reference tissue, $\Delta C_{\mathrm{T}}=\mathrm{C}_{\mathrm{T}}$ (target gene) $-\mathrm{C}_{\mathrm{T}}$ ( $\beta$-actin).

\section{Statistical analysis}

The data obtained in the current study was analyzed using a computer-aided statistical software package SPSS 20.0. The differences between means were analyzed by unpaired Student's t-test and by one way ANOVA followed by Fisher's LSD test and significance was determined at $P<0.05$.

\section{Results}

\section{Clinical signs}

After inoculating $2 \times 10^{8} \mathrm{CFU}$ of Salmonella Typhimurium, clinical symptoms appeared within $4 \mathrm{dpi}$ and included dullness, depression, inappetence and reluctance to move with both eyes closed. After one week of infection, birds showed progressive weakness, anorexia, increased thirst, diarrhoea, dropping of wings, ruffled feathers and lowering of the head.

\section{Gross pathology}

The birds in the control group did not exhibit any gross lesion in any of the organs examined throughout the experimental trial. However, in infected birds, liver revealed severe congestion, haemorrhages and enlargement. Congestion of liver was observed up to $15 \mathrm{dpi}$. Formation of pinpoint foci on the surface of the liver was observed at 9 dpi. Spleen and lungs of infected birds revealed congestion and haemorrhages from 1 to $15 \mathrm{dpi}$. Mild catarrhal enteritis, congestion and severe haemorrhages throughout the intestinal tract were noticed. Mostly, severe haemorrhages were observed in the second week post-infection.

\section{Histopathology}

Liver of birds infected with Salmonella Typhimurium revealed congestion of blood vessels at all time points. Chicks mostly showed degeneration of hepatic parenchyma along with distortion of hepatic cords and leukocytic infiltration comprising of lymphocytes and heterophils at 13 dpi (Fig. 1a, b).

\section{Haematology}

The haematological results are presented in Table-2. The mean values of $\mathrm{Hb}, \mathrm{RBC}$ and $\mathrm{PCV}$ were significantly lower $(P<0.05)$ in the infected group as compared to control group starting day 1 post-infection. There was a significant decrease in the lymphocyte count in the infected birds as compared to their respective controls $(P<0.05)$. After an initial decrease, recovery in the number of circulating lymphocytes in infected birds was observed. Further there was a significant increase in the heterophil count in the infected birds compared to their respective controls up to day 5 post- infection, followed by a gradual increase thereafter. (Table 2).

\section{Serum biochemical profile}

The mean values of glucose levels were significantly elevated in the infected birds when compared to their respective controls starting day 1 post-infection. Serum protein contents were lower in the infected group when compared with corresponding values in the control group after day 0 post-infection, as shown in Table 3 . Similarly, mean values of serum albumin were significantly lower $(P<0.05)$ in the infected group at almost all intervals except at $0 \mathrm{dpi}$ where no significant changes were seen. The AST and ALT in the infected group showed a sharp and significant increase $(P<0.05)$ when compared to their respective controls from day 1 post infection till the end of the experiment (Table 3).

\section{Elisa}

Specific serum (IgG) antibody response to Salmonella Typhimurium as the mean OD values of the chicks challenged orally with Salmonella Typhimurium increased from 0.0545 to 0.2088 up to $15 \mathrm{dpi}$ as shown in Fig. 2 . The overall antibody (IgG) response of the infected group was found to be statistically significant $(P<0.05)$. The mean OD values of the infected group were higher as compared to their respective controls.

\section{NRAMP gene family mRNA expression}

The mRNA expression levels of NRAMP1 and NRAMP2 increased significantly at all time intervals starting day 1post-infection. Following infection with Salmonella Typhimurium, expression of NRAMP1 mRNA was significantly up-regulated in all the three tissues (liver, spleen, caecum) compared to control group. Peak expression of NRAMP1 

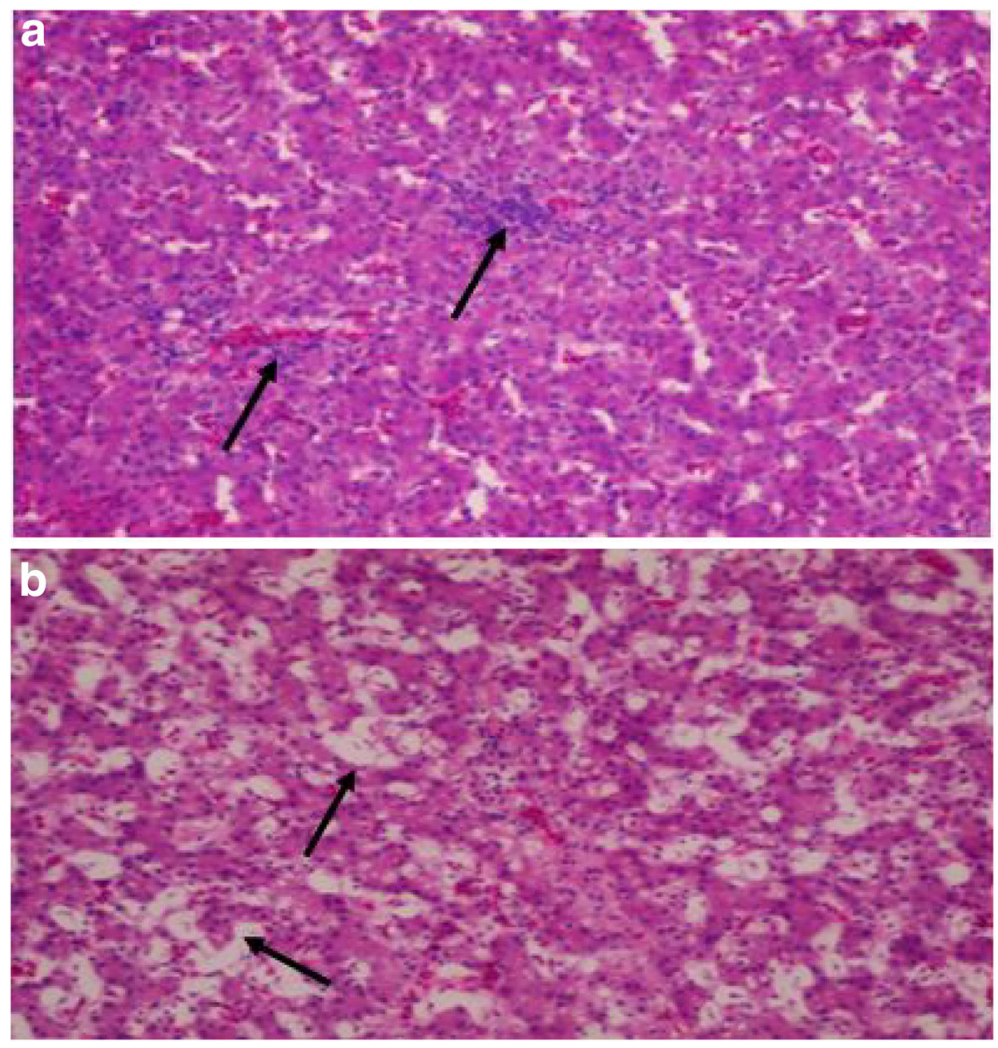

Fig. 1 a Histopathological examination of liver showing leukocytic infiltration of the infected birds at 13 dpi. H\&E $\times 10$. b Histopathological examination showing hepatic parenchyma degeneration in infected birds at $13 \mathrm{dpi}$. H\&E $\times 10$

was found on day 3 in liver (37 fold, $P<0.05$ ) (Fig. 3a), day 5 in spleen (247 fold, $P<0.05)$ (Fig. 3b) and on day 7 in caecum (144 fold, $P<0.05$ ) (Fig. 3c). Similarly, expression of NRAMP2 mRNA was significantly up-regulated in infected birds from day 1 up to day 9 (32 fold, $P<0.05$ ) in liver (Fig. 3a), up to day 5 (20 fold, $P<0.05)$ in the spleen (Fig. 3b) and up to day 9 (359 fold, $P<0.05$ ) in caecum (Fig. 3c). After day 9 in liver and caecum and day 5 in the spleen, NRAMP2 mRNA started returning to basal levels in the infected birds.

\section{Discussion}

Although expression pattern of disease resistance genes against Salmonella Typhimurium infection has been studied in mammals $[8,19,22]$, information regarding tissue-specific expression of these genes is poorly available in poultry. The non-specific clinical observations that we observed in our study were similar to the earlier studies $[29,30]$ and clinical signs of ruffled feathers, dullness and diarrhoea were also found in Fowl typhoid outbreak [31]. It was also reported in Salmonella Typhimurium infection, chicken showed high mortalities, decreased body weight, lameness, inappetence, conjunctivitis, respiratory manifestation, and pasty diarrhoea [32]. In post-mortem examination of infected birds, we observed congestion and haemorrhages in spleen and lungs, whereas necrosis, congestion and haemorrhages followed by leukocytic infiltration primarily seen in liver, as also reported previously [33, 34]. Small intestines revealed mild catarrhal enteritis, congestion and severe haemorrhages mostly in the second week of infection, as that of earlier reports [35, 36].

Haematological profile in animals is an important indicator of the physiological or pathophysiological status of the body [37]. In the present study, we observed that the mean haematological values of $\mathrm{Hb}, \mathrm{RBC}$ and $\mathrm{PCV}$ decreased markedly after Salmonella Typhimurium infection. Similar findings were also reported in Japanese quail infected with Salmonella enteric Serovar Gallinarum [38]. The mean values of $\mathrm{Hb}$ and PCV showed marked decrease from day 0 to day 9 post-infection in infected group. As with PCV, younger chicken have lower total erythrocyte count and mean corpuscular heamoglobin $(\mathrm{MCH})$ than adult ones [39]. A decrease in $\mathrm{Hb}$ and PCV in broiler chicken infected with Fowl typhoid was also reported earlier [33]. Heterophils display high phagocytic and killing activity. Thus an increase of blood heterophil number is an indication of acute infection and tissue damages [39]. Our observations related to heterophil and lymphocyte counts coincide with earlier 


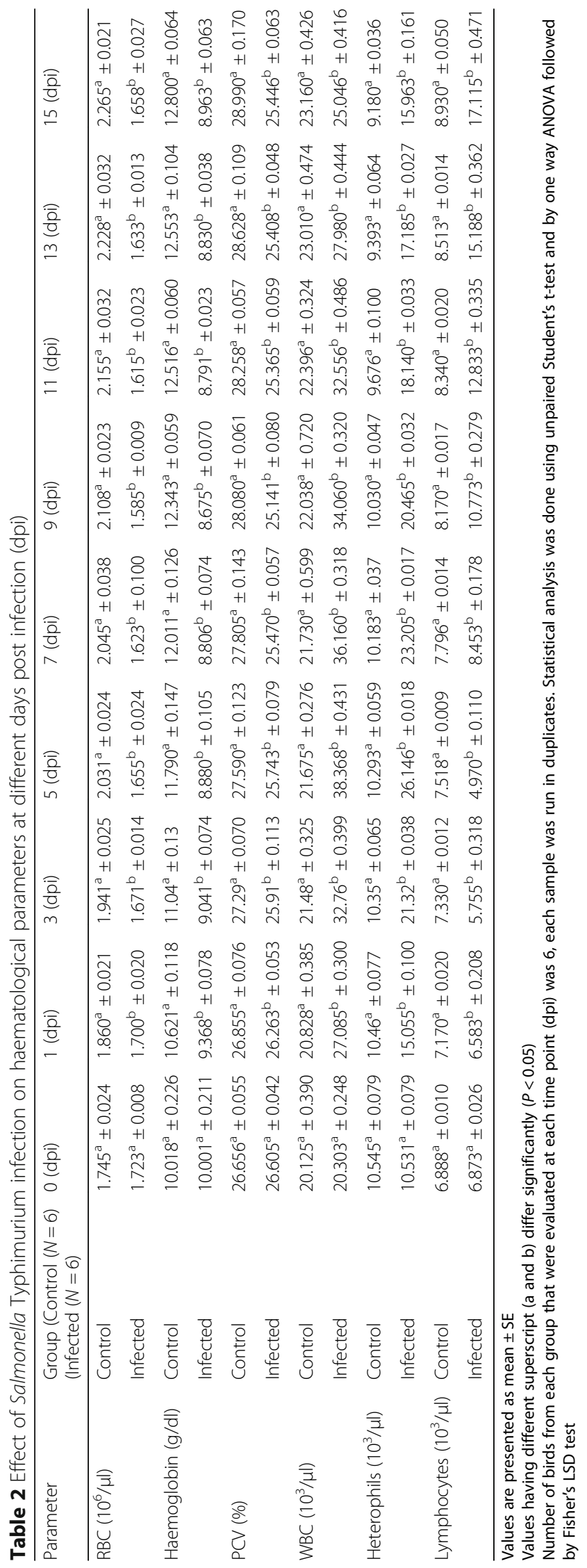




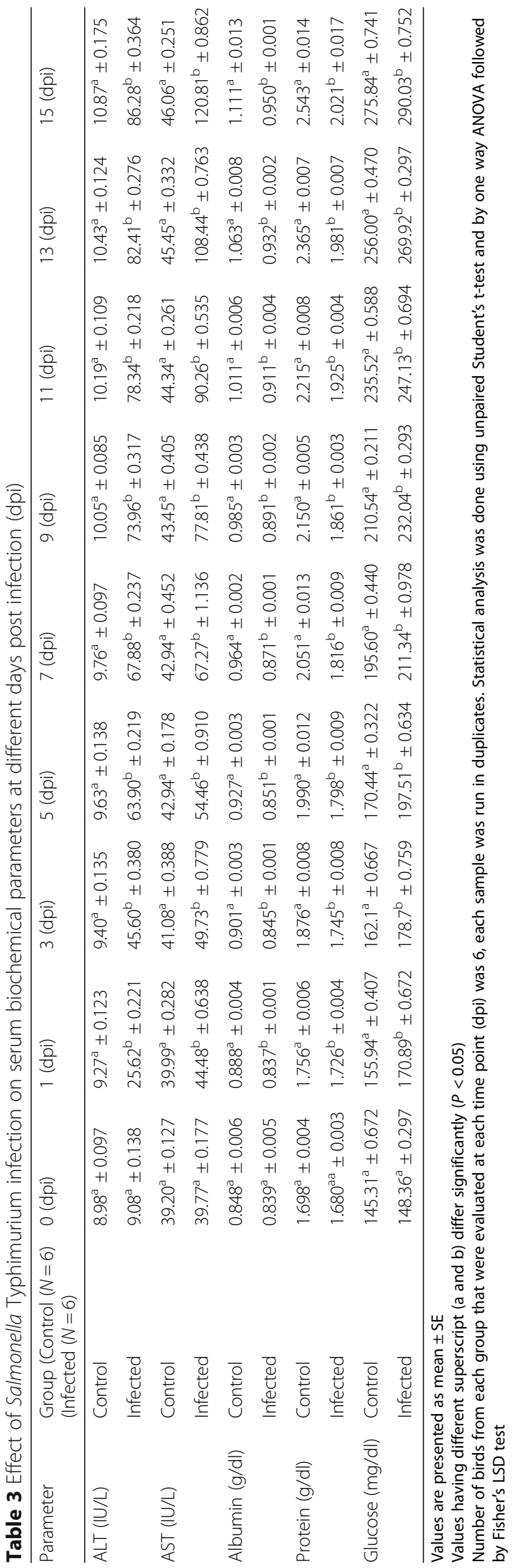




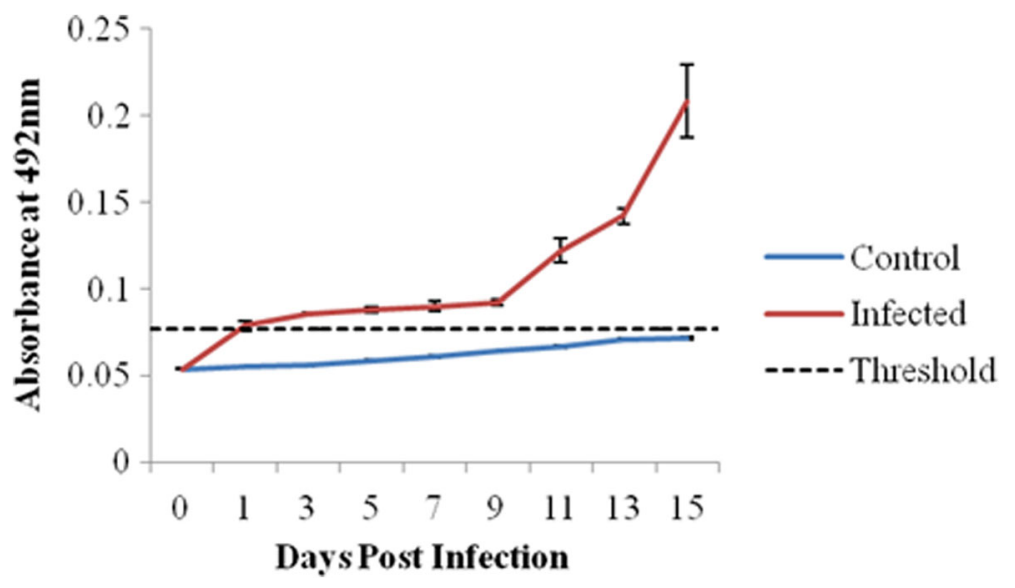

Fig. 2 Level of Salmonella Typhimurium specific lgG response (mean OD \pm SEM) detected in sera of Salmonella Typhimurium infected chicks and their respective uninfected controls at 0,1,3,5,7,9,11,13 and 15 days post infection (dpi). Number of birds from each group that were evaluated at each time point (dpi) was 6, each sample was run in duplicates. Statistical analysis was done using unpaired Student's t-test and by one way ANOVA followed by Fisher's LSD test

studies for increased blood heterophils and lymphocytes counts in Fowl typhoid infection [33].

Serum biochemistry profiling is a major tool to identify the occurrence of acute infection in birds and mammals to predict the severity of disease [40]. The increase in serum glucose of infected chickens is possibly due to increased expression of glucose transporters in intestinal tract plus more glucose consumption for bacterial replication within macrophages [41, 42]. A decrease in serum protein and albumin levels has also been reported in chicken infected with acute fowl typhoid [33, 43]. The significant decrease in protein and albumin could be due to severe liver and kidney damage of infected birds that resulted in the failure of synthesis of plasma proteins and protein loss or decreased appetite [44]. Elevation in AST and ALT in infected birds is possibly due to hepatocellular damage with alteration in cell membrane permeability and leakage of cytoplasmic ALT into the blood [45]. Elevation in AST levels has also been reported in fowl typhoid infection of chicken [33].

Strong antigen-specific cell and humoral immune responses have both been temporally linked to clearance of Salmonella Typhimurium infection in chicks [46]. Oral infection of chickens with Salmonella Typhimurium stimulates systemic immunity and a significant increase of specific humoral response after 10 days post Salmonella Typhimurium infection was found in the present study. These results are in conformity with other studies showing a steady increase in specific IgG and/or IgA starting one week after infection in chickens with Salmonella Enteritidis [47] and Salmonella Typhimurium [48].

In the present study, during the early stages of Salmonella Typhimurium infection, mRNA expression of
NRAMP1 upregulated significantly in all the three tissues under study which dropped to the basal expression levels thereafter. NRAMP1 has a major effect on survival of chicken during the first phase of Salmonella Typhimurium infection [22]. Previous studies using mouse models have shown that NRAMP1 is involved in the control of exponential growth of bacteria in reticuloendothelial organs and has also been found to be involved in Salmonella clearance [20,49]. Our findings were in accordance with the earlier studies that showed that there occurs a rapid increase in NRAMP1 expression in the lamina propia of caecum following infection with Salmonella Typhimurium and further suggesting a role of NRAMP1 in the early inflammatory response [50]. NRAMP genes often show tissue-specific expression [51]. In the present study, the NRAMP2 mRNA expression showed an initial upregulation in all the tissues of infected birds under study. In agreement with our results, an increased mRNA expression of both NRAMP2 and NRAMP1 following infection of macrophages with the intracellular bacterium Mycobacterium avium has been found [22]. Also, lipopolysaccharide (LPS) stimulation resulted in increased NRAMP2 mRNA expression in mice macrophages [52]. NRAMP2 is expressed in the intestinal tract where it plays an important role in iron uptake and in liver NRAMP2 is responsible for iron transport from endosomes into the intracellular space $[53,54]$. Unlike earlier studies on Partridge chicken, where the expression of NRAMP genes was found predominantly in liver and spleen compared to caecum [24], we found mRNA expression of NRAMP1 and NRAMP2 in salmonella-infected birds was predominant in caecum which was followed by liver and spleen. The differences of expression levels in various tissues could 

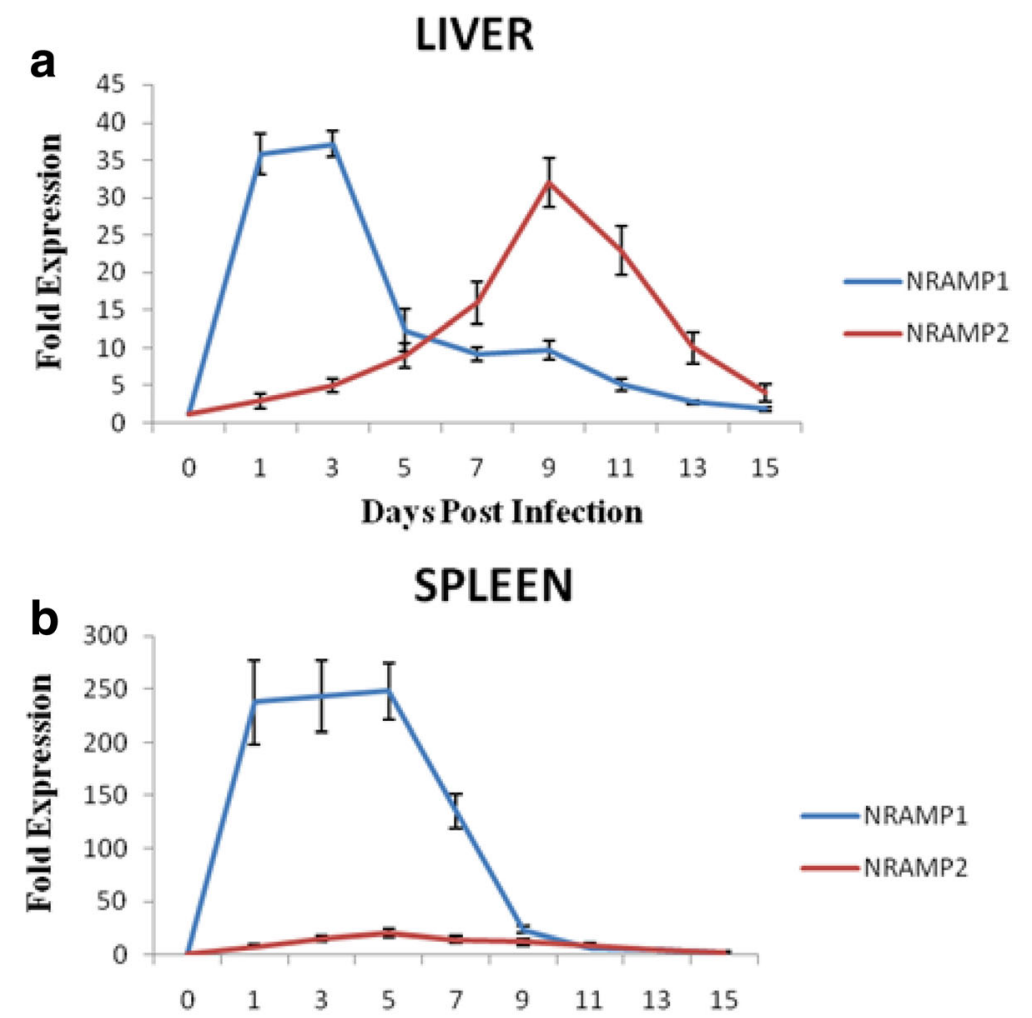

Days Post Infection

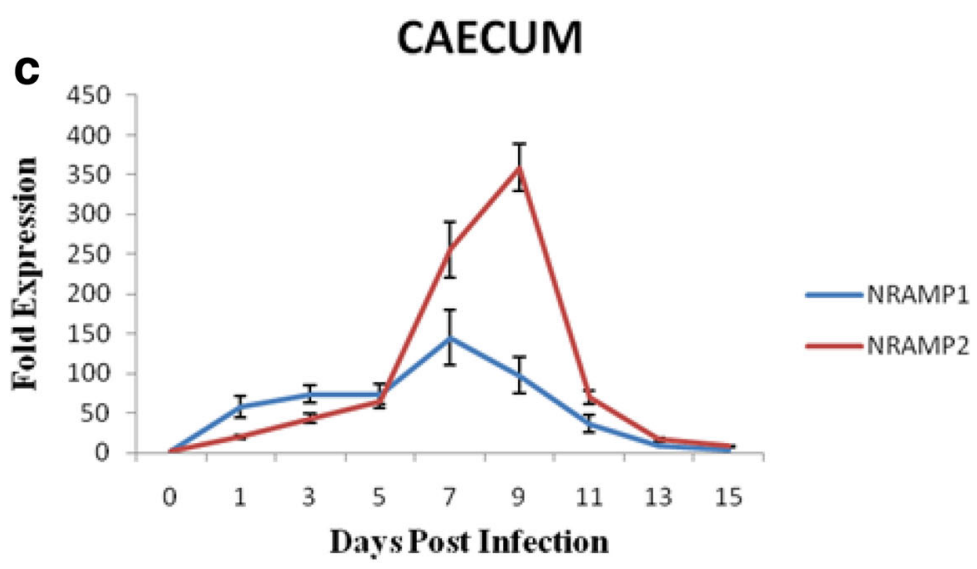

Fig. 3 a mRNA expression of NRAMP1 and NRAMP2 at 0,1,3,5,7,9,11,13 and 15 days post infection (dpi) in liver of birds infected with Salmonella Typhimurium. The values are expressed as mean fold expression \pm standard error of mean. Number of birds from each group that were evaluated at each time point (dpi) was 6, each sample was run in duplicates. Statistical analysis was done using unpaired Student's t-test and by one way ANOVA followed by Fisher's LSD test. $\mathbf{b}$ mRNA expression of NRAMP1 and NRAMP2 at 0,1,3,5,7,9,11,13 and 15 days post infection (dpi) in spleen of birds infected with Salmonella Typhimurium. The values are expressed as mean fold expression \pm standard error of mean. Number of birds from each group that were evaluated at each time point (dpi) was 6 , each sample was run in duplicates. Statistical analysis was done using unpaired Student's t-test and by one way ANOVA followed by Fisher's LSD test. c mRNA expression of NRAMP1 and NRAMP2 at 0,1,3,5,7,9,11,13 and 15 days post infection (dpi) in caecum of birds infected with Salmonella Typhimurium. The values are expressed as mean fold expression \pm standard error of mean. Number of birds from each group that were evaluated at each time point (dpi) was 6 , each sample was run in duplicates. Statistical analysis was done using unpaired Student's t-test and by one way ANOVA followed by Fisher's LSD test

be due to the higher colonization of Salmonella Typhimurium in lower GIT followed by dispersion to peripheral organs and response to defence signals in various tissues. NRAMP genes have an important role in iron homeostasis as discussed in the background of the manuscript, so evaluating the role of NRAMP family in the regulation of serum and cellular iron in a state of bacterial infection can open new avenues to investigate 
the role of iron metabolism in bacterial infection in the chicken model.

\section{Conclusion}

In conclusion, the significant increase in mRNA expression of NRAMP genes in caecum, liver and spleen of the infected chicken could enhance our understanding the importance of NRAMP genes in salmonellosis. With further well designed studies and thorough validation, the present study may serve as a base in development of blood markers for genetic selection of Salmonella resistant chicken with respect to NRAMP polymorphisms and iron metabolism. Additionally, blood investigations for biochemical and haematological parameters may aid in monitoring the physiological and pathological changes in Salmonella infection in poultry.

\section{Abbreviations}

ALT: Alanine transaminase; ANOVA: Analysis of variance; AST: Aspartate transaminase; CDNA: Complementary deoxyribonucleic acid; CFU: Colony forming unit; $\mathrm{CO}_{2}$ : Carbon dioxide; $\mathrm{C}_{\mathrm{T}}$ : Threshold value; DMT: Divalent metal ion transporter; dpi: Days post infection; FP: False positives; GIT: Gastrointestinal tract; Hb: Haemoglobin; Ig: Immunoglobulin; LPS: Lipopolysaccharide; LSD: Least square difference; MCH: Mean corpuscular heamoglobin; mRNA: Messenger ribonucleic acid; NRAMP: Natural resistance-associated macrophage protein; NSEC: National Salmonella and Escherichia Centre; OD: Optical density; PBST: Phosphate buffered saline; PCV: Packed cell volume; RBC: Red blood cells; RNA: Ribonucleic acid; SLC: Solute carrier; SLC: Solute carrier; SPSS: Statistical package for social sciences; TN: Total negatives; WBC: White blood cell

\section{Acknowledgements}

We are highly thankful to Prof. Shakil Ahmad Wani, Faculty of Veterinary science and AH, SKUAST-Kashmir for his suggestions and providing microbiology laboratory facilities. We appreciate the help and support provided by Dean Faculty of Veterinary science and AH, SKUAST-Kashmir.

\section{Availability of data and materials}

All the data supporting the results are included in the article.

\section{Authors' contributions}

MAD, RA and UU helped in expression studies, acquisition, analysis and interpretation of data. SMA designed the experiment and overall coordinated the project. PAD, ZAK and UA helped in microbiological, infectious dose preparation, and histopathological studies. NS, TAD, PTM and SAB helped in drafting of manuscript and manuscript revision. HF, RAS, NAG and $\mathrm{MH}$ helped in statistical analysis and proofreading of the manuscript. All authors read and approved the final manuscript.

\section{Ethics approval}

The samples were collected after the permission from Institutional Animal Ethics Committee on ethical standards in animal experimentation (Ref. No: AU/FVS/PS57/4461) (IAEC/15/01). All the experimental procedures were performed strictly in accordance with the approved guidelines and regulations of Institutional Animal Ethics Committee.

\section{Competing interests}

The authors declare that they have no competing interests.

\section{Publisher's Note}

Springer Nature remains neutral with regard to jurisdictional claims in published maps and institutional affiliations.

\section{Author details}

${ }^{1}$ Division of Biotechnology, Faculty of Veterinary Sciences and Animal Husbandry, Shuhama, Sher-e- Kashmir University of Agricultural Sciences and Technology - Kashmir, Srinagar, India. ${ }^{2}$ Depatment of Biochemistry,
University of Kashmir, Srinagar, India. ${ }^{3}$ Division of Veterinary Microbiology, Faculty of Veterinary Sciences and Animal Husbandry, Shuhama, SKUAST-K, Srinagar, India. ${ }^{4}$ Division of Veterinary Pathology, Faculty of Veterinary Sciences and Animal Husbandry, Shuhama, SKUAST-K, Srinagar, India. ${ }^{5}$ Division of Animal Breeding and Genetics, Faculty of Veterinary Sciences and Animal Husbandry, Shuhama, SKUAST-K, Srinagar, India. ${ }^{6}$ USDA, Agricultural Research Service, Avian Disease and Oncology Laboratory, 4279 E. Mount Hope Rd., East Lansing, MI 48823, USA.

Received: 15 November 2017 Accepted: 31 May 2018

Published online: 08 June 2018

\section{References}

1. Dar MA, Ahmad SM, Bhat SA, Ahmad R, Urwat U, Mumtaz PT, Bhat SA, Dar TA, Shah RA, Ganai NA. Salmonella typhimurium in poultry: a review. Worlds Poult Sci J. 2017:73:345-54.

2. Vivek VP, Rebecca LD, Pardeep S, Andrea RM, Kapil KC. Study of Salmonella typhimurium infection in laying hens. Front Microbiol. 2016;7:203.

3. Smith SI, Seriki A, Ajayi A. Typhoidal and non-typhoidal Salmonella infections in Africa. Eur J Clin Microbiol Infect Dis. 2016;35:1913-22.

4. Oliveira DD, Silva EN. Salmonella in table eggs: occurrence in retails, storage conditions and eggshell disinfections. Arg Bras Med Vet Zootec. 2000;52:6.

5. Crhanova M, Hradecka H, Faldynova M, Matulova M, Havlickova H, Sisak F, Rychlik I. Immune response of chicken gut to natural colonization by gut microflora and to Salmonella enterica serovar enteritidis infection. Infect Immun. 2011;79:2755-63.

6. Niedergang F, Sirard JC, Blanc CT, Kraehenbuhl JP. Entry and survival of Salmonella typhimurium in dendritic cells and presentation of recombinant antigens do not require macrophage-specific virulence factors. Proc Natl Acad Sci. 2000:14650-5.

7. R T, Idris IB, Malar PJ, Hair BM. The effects of polymorphisms in 7 candidate genes on resistance to Salmonella Enteritidis in native chickens. Poult Sci. 2013;92:900-9.

8. Nevo Y, Nelson N. The NRAMP family of metal-ion transporters. Biochimica et Biophysica Acta (BBA)-Mol Cell Res. 2006;(7):609-20.

9. Wessling RM. Nramp1 and other transporters involved in metal withholding during infection. J Biol Chem. 2015;290:18984-90.

10. Horin P, Matiasovic J. Two polymorphic markers for the horse SLC11A1 (NRAMP1) gene. Anim Genet. 2000;31:152

11. G F, Nairz M, Libby SJ, Fang FC, Weiss G. Slc11a1 (Nramp1) impairs growth of Salmonella enterica serovar typhimurium in macrophages via stimulation of lipocalin-2 expression. J Leukoc Biol. 2012;92:353-9.

12. Gruenheid S, Pinner E, Desjardins M, Gros P. Natural resistance to infection with intracellular pathogens: the Nramp1 protein is recruited to the membrane of the phagosome. The J Exp Med. 1997;185:717-30.

13. Kuhn DE, Baker BD, Lafuse WP, Zwilling BS. Differential iron transport into phagosomes isolated from the RAW264. 7 macrophage cell lines transfected with Nramp1Gly169 or Nramp1Asp169. J Leukoc Biol 1999;66:113-119.

14. Zwilling BS, Kuhn DE, Wikoff L, Brown D, Lafuse W. Role of iron in Nramp1mediated inhibition of mycobacterial growth. Infect Immun. 1999;67:1386-92.

15. Blackwell JM, Goswami T, Carlton AW, Sibthorpe D, Papo N, Jacqueline K, Susan SE, Miller N, Christopher SP, Mohammed H, Ibrahim M. SLC11A1 (formerly NRAMP1) and disease resistance. Cell Microbiol. 2001;3:773-84.

16. Canonne-Hergaux F, Gruenheid S, Ponka P, Gros P. Cellular and subcellular localization of the Nramp2 iron transporter in the intestinal brush border and regulation by dietary iron. Blood. 1999:93:4406-17.

17. Fleet JC. Identification of Nramp2 as an iron transport protein: another piece of the intestinal iron absorption puzzle. Nutr Rev. 1998;56:88-9.

18. Wood RJ, Han O. Recently identified molecular aspects of intestinal iron absorption. J Nutr. 1998;128:1841-4.

19. Paul W. Genetic resistance to Salmonella infection in domestic animals. Res Vet Sci. 2004;76:165-9.

20. Vidal SM, Malo D, Vogan K, Skamene E, Gros P. Natural resistance to infection with intracellular parasites: isolation of a candidate for Bcg. Cell. 1993;73:469-85.

21. W L, Kaiser MG, Lamont SJ. Natural resistance-associated macrophage protein 1 gene polymorphisms and response to vaccine against or challenge with Salmonella enteritidis in young chicks. Poult Sci. 2003:82:259-66.

22. Hu J, Bumstead N, Barrow P, Sebastiani G, Olien L, Morgan K, Malo D. Resistance to salmonellosis in the chicken is linked to NRAMP1 and TNC. Genome Res. 1997;7:693-704. 
23. Vidal SM, Gros P, Skamene E. Natural resistance to infection with intracellular parasites: molecular genetics identifies Nramp1 as the Bcg/lty/ Lsh locus. J Leukoc Biol. 1995;58:382-90.

24. He XM, Fang MX, Zhang ZT, Hu YS, Jia XZ, He DL, Liang SD, Nie QH, Zhang $X Q$. Characterization of chicken natural resistance-associated macrophage protein encoding genes (Nramp1 and Nramp2) and association with salmonellosis resistance. Genet Mol Res. 2013;12:618-30.

25. Edwards PR, Ewing WH. Identification of Enterobacteriaceae, Burgess Publication Company, Minneapolis, Minnesota. 3rd ed; 1972.

26. Wani SA, Hussain I, Beg SA, Rather MA, Kabli ZA, Mir MA, Nishikawa Y. Diarrhoeagenic Escherichia coli and salmonellae in calves and lambs in Kashmir: absence, prevalence and antibiogram. Rev sci tech Off int Epiz. 2013:32:1-7.

27. Luna LG. Manual of histologic staining methods of the armed forces institute of pathology. 3rd ed. New York, NY: McGraw-Hill; 1968.

28. Holt PS, Gast RK, Porter RE, Stone HD. Hyporesponsiveness of the systemic and mucosal humoral immune systems in chickens infected with Salmonella enterica serovar enteritidis at one day of age. Poult Sci. 1999;78:1510-7.

29. Shivprasad HL. Fowl typhoid and pullorum disease. Review Science Technology. 2000:19:405-24.

30. Chacana PA, Terzolo HR. New light on old views of avian Pullorosis: avian Typhosis. Rev Inst Med Trop. 2003;84:14-20.

31. Bhattacharya A, Majumder P, Isolation DMK. Characterization and antibiotic spectra of S. Gallinarum from an outbreak of fowl typhoid in adult broiler parent flock in Tripura. Indian j. Comp. Microbiol. Immunol Infect Dis. 2001;22:56-8.

32. Sharkawy H, Tahoun A, Gohary AE, Abasy M, Khayat F, Gillespie T, Kitade Y, Hafez HM, Neubauer H, Adawy H. Epidemiological, molecular characterization and antibiotic resistance of Salmonella enterica serovars isolated from chicken farms in Egypt. Gut Pathog. 2017;10:8.

33. Shah SN, Kamil SA, Darzi MM, Mir MS, Bhat SA. Haematological and some biochemical changes in experimental fowl typhoid infection in broiler chickens. Comp Clin Path. 2013;22:83-91.

34. Chishti MA, Khan MZ, Irean M. Pathology of liver and spleen in avian salmonellosis. Pak Vet J. 1985:5157-60.

35. Parsons BN, Humphrey S, Salisbury AM, Mikoleit J, Hinton JC, Gordon MA, Wigley P. Invasive non-typhoidal Salmonella typhimurium ST313 are not host-restricted and have an invasive phenotype in experimentally infected chickens. PLoS Negl Trop Dis. 2013;77:10.

36. Withanage GS, Kaiser $P$, Wigley P, Powers $C$, Mastroeni $P$, Brooks $H$, Barrow P, Smith A, Maskell D, McConnell I. Rapid expression of chemokines and proinflammatory cytokines in newly hatched chickens infected with Salmonella enterica serovar typhimurium. Infect Immun. 2004;72:2152-9.

37. Khan AT, Zafar F. Hematological study in response of varying doses of estrogen in broiler chicken. Int J Poult Sci. 2005;4:748-51.

38. Barde JO, Bale O, Oladele SB, Fatihu MY, Kumbish PR, Rimfa AG, Teki IS, Moses GD, Ahmed JS, Okewole PA. Study of some Haematological parameters of Japanese quail (Coturnix coturnix japonica) experimentally infected with Salmonella enterica Serovar Gallinarum. Annu res rev biol. 2015;7:222-8.

39. Greenacre CB, Morishita $Y$, editors. Backyard poultry medicine and surgery, a guide for veterinary practitioners. Ames: John Wiley and Sons Inc; 2015.

40. Smith CM, Reynard A. Text Book of Pharmacology, W. B. Saunders, London, 1992.

41. Feng $Y$, Yang $X J$, Wang $Y B$, Li WL, Liu Y, Yin RQ, Yao JH. Effects of immune stress on performance parameters, intestinal enzyme activity and mRNA expression of intestinal transporters in broiler chickens. ASIAN AUSTRAL J ANIM. 2012;25:701

42. Bowden SD, Rowley G, Hinton JC, Thompson A. Glucose and glycolysis are required for the successful infection of macrophages and mice by Salmonella enterica serovar typhimurium. Infect and immunity. 2009;77:3117-26.

43. Kokosharov T. Bacterial colonization and endotoxin activity during experimental acute fowl typhoid in chickens. Onder J Vety Res. 2000;67:297.

44. Coles EH. Vet Clin Pathol, 4th edn. Saunders WB Company, Philadelphia, 1986: 486.

45. Benjamin MN. Outline of veterinary clinical pathology, University, lowa; 1978. p. 229-32

46. Saif YM, Barnes HJ, Glisson Glisson RJ, Fadly MA, RL MD, Swayne ED. Diseases of Poultry. 11th ed.

47. Olabisi IO, Peter HS. Salmonella Enteritidis experimental infection in chickens; effects of challenge dose on serum immunoglobulin $\mathrm{G}$ antibody response. Afr J Biotechnol. 2008;20:3783-7.
48. Hassan JO, Barrow PA, Mockett APA, McLeod S. Antibody response to experimental Salmonella typhimurium infection in chickens measured by ELISA. Vet Rec. 1990;12:519-22.

49. Caron J, Loredo-Osti JC, Laroche L, Skamene E, Morgan K, Malo D. Identification of genetic loci controlling bacterial clearance in experimental Salmonella enteritidis infection: an unexpected role of Nramp1 (SIc11a1) in the persistence of infection in mice. Genes Immun. 2002;(4):196-204.

50. Yanet V, Guntram AG, Julian AG, Bryan C, Phillipe G, Bruce AV, Brett F. Nramp1 drives an accelerated inflammatory response during Salmonellainduced colitis in mice. Cell Microbiol. 2009;11:351-62.

51. Xiangjun Z, Yang Y. Differential expression of rice Nramp genes in response to pathogen infection, defense signal molecules and metal ions. Physiol Mol Plant Pathol. 2004;65:235-43.

52. Wardrop SL, Richardson DR. Interferon-g and lipopolysaccharide regulate the expression of Nramp2 and increase the uptake of iron from low relative molecular mass complexes by macrophages. Eur J Biochem. 2000;267:6586-93.

53. Simovich MJ, Conrad ME, Umbreit JN, Moore EG, Hainsworth LN, Smith HK. Cellular location of proteins related to iron absorption and transport. Am J Hematol. 2002;69:164-70.

54. Foot NJ, Gembus KM, Mackenzie K, Kumar S. Ndfip2 is a potential regulator of the iron transporter DMT1 in the liver. Sci Rep. 2016;6:24045.

\section{Ready to submit your research? Choose BMC and benefit from:}

- fast, convenient online submission

- thorough peer review by experienced researchers in your field

- rapid publication on acceptance

- support for research data, including large and complex data types

- gold Open Access which fosters wider collaboration and increased citations

- maximum visibility for your research: over $100 \mathrm{M}$ website views per year

At BMC, research is always in progress.

Learn more biomedcentral.com/submissions 